\title{
Mesoproterozoic and Paleoproterozoic subcontinental lithospheric mantle domains beneath southern Patagonia: Isotopic evidence for
} its connection to Africa and Antarctica

\author{
Andrea Mundl' ${ }^{1}$, Theodoros Ntaflos ${ }^{1}$, Lukas Ackerman'2,3, Michael Bizimis ${ }^{4}$, Ernesto A. Bjerg ${ }^{5}$, and Christoph A. \\ Hauzenberger ${ }^{6}$ \\ 1Department of Lithospheric Research, University of Vienna, Althanstrasse 14, 1090 Vienna, Austria \\ ${ }^{2}$ Institute of Geology v.v.i., Academy of Sciences of the Czech Republic, Rozvojová 269, 16500 Prague 6 - Lysolaje, Czech Republic \\ ${ }^{3}$ Czech Geological Survey, Geologická, 15200 Prague 5, Czech Republic \\ 4Department of Earth and Ocean Sciences, University of South Carolina, 701 Sumter Street, Columbia, South Carolina 29208, USA \\ 5INGEOSUR (CONICET-UNS) and Departamento de Geología, Universidad Nacional del Sur, San Juan 670, B8000ICN Bahía \\ Blanca, Argentina \\ ${ }^{6}$ Institute for Earth Sciences, University of Graz, Heinrichstrasse 26, 8010 Graz, Austria
}

\begin{abstract}
New isotopic studies on mantle xenoliths from Santa Cruz Province, southern Patagonia, Argentina, reveal that at least three discrete subcontinental lithospheric mantle (SCLM) domains-the Deseado Massif, Tres Lagos, and Pali Aike-form the southernmost part of South America. Re-Os systematics yield early Paleoproterozoic (up to 2.5 Ga) SCLM formation ages (rhenium depletion ages, $T_{\mathrm{RD}}$ ) for Pali Aike spinel peridotites, while samples from the Deseado Massif and Tres Lagos indicate a younger SCLM origin with Neoproterozoic to Mesoproterozoic (0.9-1.3 Ga) and Mesoproterozoic to late Paleoproterozoic (1.3-1.9 Ga) $T_{\mathrm{RD}}$ ages, respectively. Hf-Sr-Nd isotopic compositions indicate metasomatic overprinting of the majority of the samples, which, however, has not affected the Os isotopic system. Based on similar formation ages, the geological evolution of the Deseado Massif is most likely connected to the evolution of the Namaqua-Natal belt of South Africa. $T_{\mathrm{RD}}$ ages from SCLM domains underneath Tres Lagos and Pali Aike indicate a common origin with crustal sections from Shackleton Range, Antarctica, positioning the southern tip of South America closer to west Antarctica in the reconstructed Rodinia supercontinent than previously assumed.
\end{abstract}

\section{INTRODUCTION}

The origin of the Patagonian continental terrane is highly debated. Whether Patagonia is a uniform part of the southernmost South American continental plate or an assemblage of fragments with different mantle roots is a matter of controversy (Stern et al., 1999; Pankhurst et al., 2006; Ramos, 2008; Schilling et al., 2008; Wang et al., 2008). As a result of the rarity of southern Patagonian crustal basement outcrops, which could provide precise evidence on the timing of crustal formation, Patagonia's geological evolution has remained enigmatic.

The formation of ancient continental terranes is related to the formation of their underlying subcontinental lithospheric mantle (SCLM) roots, as continental crust is formed by the extraction of melt of a mantle section that has experienced variable degrees of partial melting. This residual depleted lithospheric mantle coevally forms the root of the overlying continental crust (e.g., Griffin et al., 1999a, and references therein; Pearson, 1999). This relationship permits us to use the determined timing of lithospheric mantle formation as a proxy for the timing of the genesis of continental terranes. Hence, mantle xenoliths brought to the surface by magmas can provide detailed information on SCLM sections. The Re-Os isotopic system is, compared to other isotopic systems, less sensi- tive to mantle metasomatism, providing reliable information on the timing of melt extraction events leading to the formation of the SCLM and its overlying crust (Walker et al., 1989; Carlson, 2005). We have used the Re-Os isotopic system on carefully selected mantle xenoliths to determine the timing of the stabilization of SCLM domains beneath southern Patagonia. In addition, Hf-Nd-Sr isotopic data obtained from leached clinopyroxene (cpx) separates of those samples analyzed for Os isotopic composition are presented to provide better insight into the origin and complex history of South Patagonia.

\section{GEOLOGICAL SETTING}

Patagonia, in southern South America, is geographically defined as the region south of Río Colorado and east of the Andean Cordillera. The only basement outcrop in southern Patagonia is the Deseado Massif which covers 60,000 $\mathrm{km}^{2}$ (Fig. 1). Pankhurst et al. (2003) presented Mesoproterozoic (1.3-1.6 Ga) Sm-Nd mantle separation ages from Deseado Massif granites, amphibolites, and schists. The basement south of the Deseado Massif is covered by sedimentary sequences $>7 \mathrm{~km}$ thick, reflecting several episodes of basin formation of Triassic to Cretaceous age. The Late Jurassic breakup of Gondwana resulted in voluminous rhyolitic volcanism in southern Patagonia (Bruhn et al., 1978; Kay et

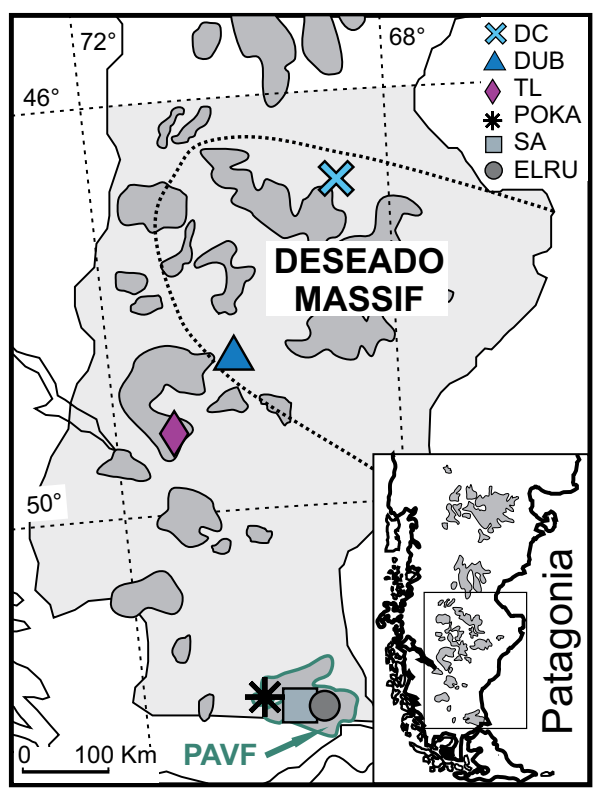

Figure 1. Simplified geological map of southern Patagonia. Light gray area is Santa Cruz Province. Dark gray fields are Tertiary/ Quaternary flood basalts. Green outlined field is Pali Aike volcanic field (PAVF). DCDon Camilo; DUB-Gobernador Gregores; TL-Tres Lagos; POKA-Potrok Aike; SASalsa; ELRU-EI Ruido.

al., 1989). Since then, subsidence and sedimentation have dominated the area, forming the Magellan Basin (Wang et al., 2008). Phanerozoic rhenium depletion ages $\left(T_{\mathrm{RD}}\right)$ obtained by Wang et al. (2008) have led them to interpret the basement beneath Pali Aike (Fig. 1) to be a young accretionary lithosphere that was either part of the Deseado Massif or a separate part that accreted to the Deseado Massif during the Paleozoic.

\section{SAMPLES AND RESULTS}

\section{Sample Description}

From a large number ( $>200)$ of mantle xenoliths collected at six different sites throughout Santa Cruz Province, 11 anhydrous spinel 
lherzolites and 13 anhydrous spinel harzburgites were chosen and studied in detail (see the GSA Data Repository ${ }^{1}$ for selection criteria). Host rocks are Pliocene and Quaternary alkali basalts, basanites, and pyroclastics (D'Orazio et al., 2000) that erupted in the back-arc region of the Andean subduction zone (Stern et al., 1990).

Sample localities are Don Camilo (DC) and Gobernador Gregores (DUB) within the Deseado Massif; Tres Lagos (TL); and Potrok Aike (POKA), El Ruido (ELRU), and Salsa (SA) from within the Pali Aike volcanic field (Fig. 1).

Bulk-rock major element analyses show that samples from Pali Aike (POKA, SA, ELRU) and Tres Lagos have mean $\mathrm{Al}_{2} \mathrm{O}_{3}$ contents and $\mathrm{Mg} \#\left[\mathrm{Mg} /\left(\mathrm{Mg}+\mathrm{Fe}_{\text {tot }}\right)\right]$ of $1.46 \mathrm{wt} \%$ and 0.91 , respectively, and are generally more depleted than mantle xenoliths found in the Deseado Massif with mean $\mathrm{Al}_{2} \mathrm{O}_{3}$ contents and $\mathrm{Mg \#}$ of $2.08 \mathrm{wt} \%$ and 0.90 , respectively. Bulk-rock rare earth element (REE) compositions reveal elevated light REE (LREE) in the majority of Pali Aike samples (ELRU and SA). All POKA samples exhibit a hump in middle REE (MREE) suggesting melt percolation processes. Except for sample TL143, Tres Lagos samples have slightly elevated LREE compositions. Deseado Massif samples exhibit roughly flat REE patterns with a minor increase in LREE in DC and a minor MREE and stronger LREE enrichment in DUB samples (Table DR2 and Fig. DR2 in the Data Repository).

\section{Sulfide Petrography}

The modal abundances of sulfides in the studied mantle xenoliths are generally low and do not correlate with fertility indices (e.g., bulk rock $\mathrm{Al}_{2} \mathrm{O}_{3}$ ). Sulfides occur either interstitially or as spherical inclusions and trails preferentially in olivine and orthopyroxene (Table DR4). Primary enclosed sulfides with diameters ranging from 30 to $150 \mu \mathrm{m}$ are multiphase grains formed mainly of monosulfide solid solution, pentlandite, and chalcopyrite, with rare Pt- and/or Ir-rich microphases (Figs. DR3a-DR3f). Interstitial sulfides are commonly irregularly shaped and can be found in melt pockets, around spongy $\mathrm{cpx}$, and as up to $10 \mu \mathrm{m}$ elongated or round sulfide droplets in intergranular propagating fresh host basalt glass consisting mainly of Ni monosulfide solid solution, pyrrhotite, or pentland-

${ }^{1}$ GSA Data Repository item 2015029, detailed information on sample localities; analytical methods; isotopic results and HSE abundances (Table DR1 and Figure DR1); bulk rock major and trace element compositions (Table DR2) and bulk rock primitive mantle normalized REE patterns (Figure DR2); clinopyroxene major and trace element concentrations (Table DR3); sulfide occurrences (Table DR4); backscattered electron images and photomicrographs of primary and secondary sulfides (Figures DR3 and DR4), is available online at www.geosociety.org/pubs/ft2015.htm, or on request from editing@geosociety.org or Documents Secretary, GSA, P.O. Box 9140, Boulder, CO 80301, USA. ite, as well as sulfide alteration products (Figs. DR3g-DR31).

\section{Re-Os Concentrations and Os-Hf-Nd-Sr \\ Isotopic Systematics}

Bulk-rock osmium concentrations vary from 0.5 to $3.3 \mathrm{ppb}$ while rhenium contents are generally low, between $0.002 \mathrm{ppb}$ and $0.105 \mathrm{ppb}$. Initial ${ }^{187} \mathrm{Os} /{ }^{188} \mathrm{Os}$ ratios, calculated back to time of eruption (4 Ma), are subchondritic, ranging from 0.1114 to 0.1266 , except in one sample from the Deseado Massif (DC08) exhibiting a suprachondritic Os isotopic ratio of 0.1327 (Fig. 2). Osmium isotopic ratios do not correlate with either ${ }^{187} \mathrm{Re} /{ }^{188} \mathrm{Os}$ or bulk-rock $\mathrm{Al}_{2} \mathrm{O}_{3}$ (Figs. 2A and 2B). In samples from the Deseado Massif (DUB and DC), ${ }^{187} \mathrm{Os} /{ }^{188} \mathrm{Os}$ ratios lead to $T_{\mathrm{RD}}$ ages between 0.5 and $1.3 \mathrm{Ga}$. Except for sample TL142 (0.6 Ga), samples from Tres Lagos yield older $T_{\mathrm{RD}}$ ages ranging from 1.3 to $1.9 \mathrm{Ga}$. The largest variation in calculated $T_{\mathrm{RD}}$ ages can be found in the Pali Aike sample suite, with Neoto early Paleoproterozoic $T_{\mathrm{RD}}$ ages $(0.7-2.5 \mathrm{Ga})$.

$\mathrm{Hf}$ isotopic analyses from Deseado Massif cpx separates yield $\varepsilon_{\mathrm{Hf}}$ ranging from +5.8 to +41.5 . One sample (DC18) yields a model age $\left(T_{\mathrm{MA}}\right)$ of $1.2 \mathrm{Ga}$, consistent with Mesoproterozoic $T_{\mathrm{RD}}$ ages determined from Os isotopic analyses for Deseado Massif samples. $\varepsilon_{\mathrm{Hf}}$ values from Tres Lagos samples lie between +15.2 and +52.0. Sample TL142 yields a calculated $T_{\text {MA }}$ age of $1.8 \mathrm{Ga}$. Samples from Pali Aike show a broad range in $\varepsilon_{\mathrm{Hf}}$ values from -17.1 to +23.0 . Sample ELRU3, with $\varepsilon_{\mathrm{Hf}}$ of +23.0 , yields a $T_{\mathrm{MA}}$ age of $2.7 \mathrm{Ga}$, slightly older than the oldest Pali Aike $T_{\mathrm{RD}}$ ages (2.4-2.5 Ga). Laser ablation analyses of cpx reveal no metasomatic addition of Hf or Lu to samples DC18, TL142, or ELRU3
(Table DR3). Hence, calculated $T_{\text {MA }}$ ages can be considered reliable. Hf isotopic ratios from the remaining South Patagonian peridotites yield unrealistic future or impossibly old $T_{\mathrm{MA}}$ ages and suggest a resetting of the Lu-Hf system, also evidenced by enriched cpx trace element concentrations (Table DR3).

$\mathrm{Sr}$ and $\mathrm{Nd}$ isotopic compositions in the Deseado Massif mantle xenoliths yield variable ${ }^{87} \mathrm{Sr} /{ }^{86} \mathrm{Sr}$ ratios ranging from 0.70278 to 0.70588 and ${ }^{143} \mathrm{Nd} /{ }^{144} \mathrm{Nd}$ ratios between 0.51223 and 0.51328 (present-day $\varepsilon_{\mathrm{Nd}}$ of -7.9 to +11.2 ). Samples from Tres Lagos show $\mathrm{Sr}$ and Nd isotopic ratios between 0.70225 and 0.70320 and 0.51283 and $0.51321\left(\varepsilon_{\mathrm{Nd}}+3.32\right.$ to +11.2$)$, respectively. $\mathrm{Sr}$ and $\mathrm{Nd}$ isotopic compositions in Pali Aike cpx range from 0.70282 to 0.70769 and 0.51209 to $0.51318\left(\varepsilon_{\mathrm{Nd}}-10.7\right.$ to +10.6$)$, respectively, and correlate well with each other as well as with $\mathrm{Hf}$ isotopes (Figs. 3A-3C). Sr and $\mathrm{Nd}$ isotopic results combined with cpx trace element analyses reveal a cryptic metasomatic overprint of the majority of our studied samples.

\section{DISCUSSION}

\section{SCLM Formation Ages}

A scatter in Os isotopic ratios and the absence of a correlation thereof with melt depletion indices (e.g., bulk rock $\mathrm{Al}_{2} \mathrm{O}_{3}$ ) within a sample suite is often interpreted to indicate metasomatic overprint (i.e., Pearson et al., 1995; Brandon et al., 1996; Handler et al., 2005). However, our samples do not show significant variations in their highly siderophile element abundances (i.e., enrichment in the palladium group of the platinum-group elements, Ir-Ru fractionation; Fig. DR1) as is typical for many metasomatized

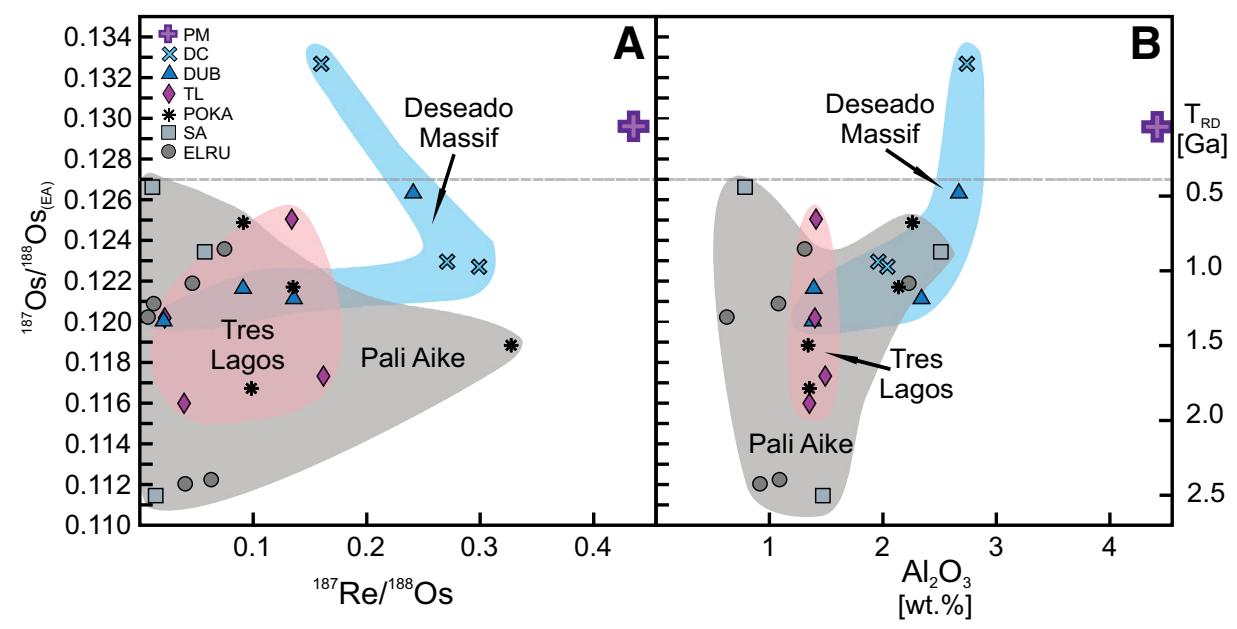

Figure 2. Bulk-rock ${ }^{187} \mathrm{Os} /{ }^{188} \mathrm{Os}$ versus ${ }^{187} \mathrm{Re} /{ }^{188} \mathrm{Os}(\mathrm{A})$ and bulk-rock $\mathrm{Al}_{2} \mathrm{O}_{3}$ [wt\%] (B), respectively, of 24 spinel peridotites with reference to primitive mantle (PM) values from Meisel et al. (1996) $\left({ }^{187} \mathrm{Os} /{ }^{188} \mathrm{Os}=0.1296\right.$ and $\left.{ }^{187} \mathrm{Re} /{ }^{188} \mathrm{Os}=0.4353\right)$ and $\mathrm{McDonough}$ and Sun (1995) $\left(\mathrm{Al}_{2} \mathrm{O}_{3}=4.45 \mathrm{wt} \%\right)$. Rhenium depletion ages $\left(T_{\mathrm{RD}}\right)$ on right are mantle formation ages calculated using PM values from Meisel et al. (1996) at time of eruption (4 Ma). Gray dashed line is ${ }^{187} \mathrm{Os} /{ }^{188} \mathrm{Os}$ chondrite value (0.127; Walker and Morgan, 1989). Fields for subcontinental lithospheric mantle domains: Deseado Massif (DC and DUB), Tres Lagos (TL), and Pali Aike (POKA, SA, ELRU). Symbols and abbreviations are as in Figure 1. 
Figure 3. Isotopic ratios of clinopyroxene separates. A: ${ }^{143} \mathrm{Nd} /{ }^{144} \mathrm{Nd}$ versus ${ }^{87} \mathrm{Sr} /{ }^{36} \mathrm{Sr}$, showing a well-defined negative correlation. B: $\varepsilon_{\mathrm{Hf}}$ versus $\varepsilon_{\mathrm{Nd}}$ C: $\varepsilon_{\mathrm{Hf}}$ versus ${ }^{87} \mathrm{Sr} /{ }^{86} \mathrm{Sr}$ of the three subcontinental lithospheric mantle domains. BSE-bulk silicate earth. Fields in A for depleted mantle (DMMa and DMMb), prevalent mantle (PREMA), high $\mu$ (HIMU), and enriched mantle I and II (EM-I and EM-II) are from Zindler and Hart (1986). Mid-oceanic-ridge basalt (MORB) and ocean island basalt (OIB) fields in B and $C$ are from Nowell et al. (1998, and references therein). Symbols and other abbreviations are as in Figure 1.

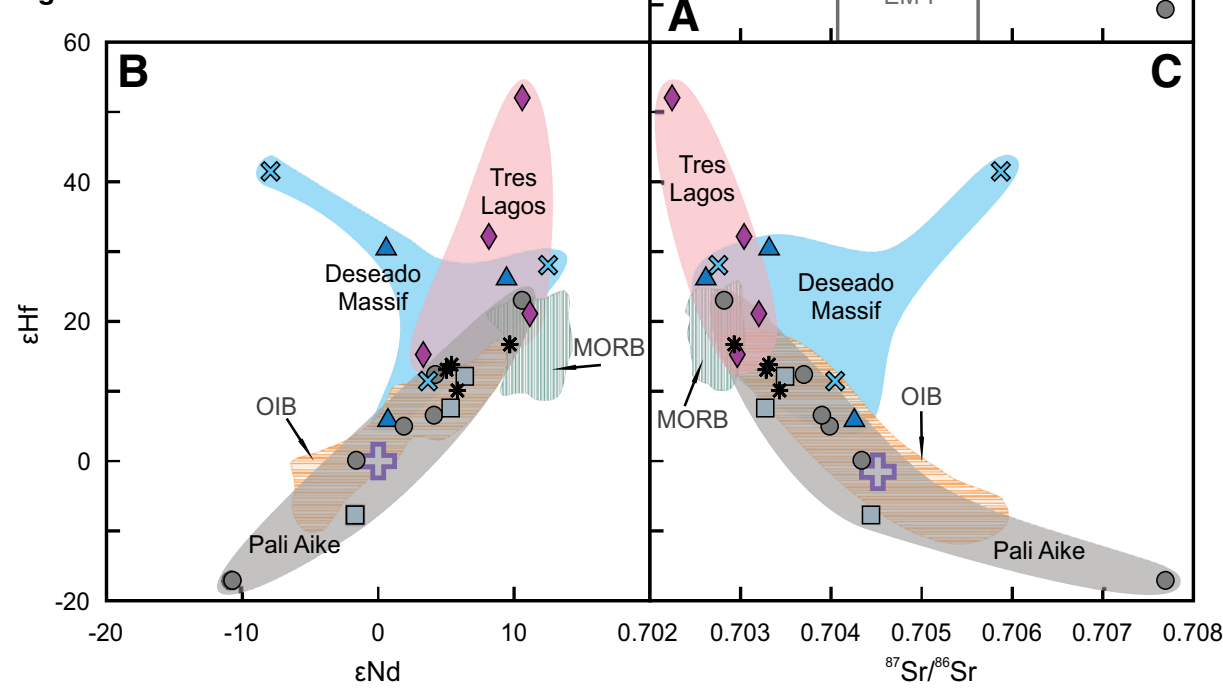

peridotites (e.g., Lorand et al., 2013, and references therein).

Two populations of sulfides have been petrographically identified in our South Patagonian samples (Table DR4). While the Os isotopic composition in the majority of the samples is most likely controlled by primary sulfide inclusions in silicates (Alard et al., 2000), some samples also exhibit an abundance of secondary sulfides, which may lead to mixed whole-rock Os isotopic compositions. Clinopyroxene and bulk-rock primitive mantle-normalized REE patterns suggest that percolating melts have affected the bulk compositions of all POKA samples (Tables DR2 and DR3; Fig. DR2). This may have led to an addition of secondary sulfides prior to host basalt entrainment, and hence, resulted in a refertilization of the samples leading to $T_{\mathrm{RD}}$ ages younger than their actual melt depletion ages. Secondary sulfides in most other samples are found in fresh intergranular propagating glass and have likely been added to the xenoliths by host basalt infiltration. It is important to point out that the samples with the oldest calculated $T_{\mathrm{RD}}$ ages from each studied sample suite also exhibit the highest primary to secondary sulfide ratio, where secondary sulfides can only rarely be found within a thin section (Table DR4). Thus, we infer that the Os isotopic composition in those samples is likely controlled by primary sulfides and yields minimum but reasonable $T_{\mathrm{RD}}$ ages.

Calculated $T_{\mathrm{RD}}$ ages (Fig. 4) from DUB and DC group at ca. $1 \mathrm{Ga}$, with the oldest $T_{\mathrm{RD}}$ age at $1.3 \mathrm{Ga}$. The Tres Lagos samples yield $T_{\mathrm{RD}}$ ages of up to $1.9 \mathrm{Ga}$. Samples from Pali Aike exhibit the broadest range in $T_{\mathrm{RD}}$ ages with three samples displaying a peak at ca. 2.4 Ga. Even though samples from within one sample suite yield variable $T_{\mathrm{RD}}$ ages, Figure 4 clearly shows that the oldest samples come from Pali Aike with an age of up to $2.5 \mathrm{Ga}$, followed by the Tres Lagos sample suite with the oldest determined $T_{\mathrm{RD}}$ ages of $1.9 \mathrm{Ga}$, and the "youngest" sample suite from Santa Cruz Province, the Deseado Massif, with $T_{\mathrm{RD}}$ ages of up to $1.3 \mathrm{Ga}$.

\section{SCLM Domains}

\section{Deseado Massif}

The determined SCLM formation ages for DC and DUB mantle xenoliths match that of the Mesoproterozoic basement interpreted by Pankhurst et al. (2003), as well as Meso- to Paleoproterozoic $T_{\mathrm{RD}}$ ages from Cerro Redondo and Estancia Lote 17 (Schilling et al., 2008). Rodinia and Gondwana reconstructions have placed the Deseado Massif close to South Africa and West Antarctica (e.g., Dalziel et al., 2000; König and
Jokat, 2006). U-Pb zircon data from exposed basement rocks of the Natal belt and Mesoproterozoic ages from Dronning Maud Land in East Antarctica suggest a continental crust formation between 1.2 and 1.0 Ga (McCourt et al., 2006; Jacobs et al., 1996). These ages are similar to our determined $T_{\mathrm{RD}}$ ages of up to $1.3 \mathrm{Ga}$ for the Deseado Massif mantle xenoliths, as well as to Mesoproterozoic ages (1.1-1.0 Ga) obtained for basement rocks from Cape Meredith Complex, West Falkland-Malvinas (Thomas et al., 2000, and references therein). We suggest that the Patagonian SCLM fragment represented by Deseado Massif mantle xenoliths was accreted together with other microcontinents during the formation of Rodinia and stayed contiguous to South Africa and West Antarctica until the Mesozoic breakup of Gondwana.

\section{Tres Lagos and Pali Aike}

$T_{\mathrm{RD}}$ ages of the Tres Lagos samples are distinctly older than Deseado Massif ages, indicating a different origin. Ntaflos et al. (2007) proposed that the SCLM beneath Tres Lagos represents an isolated old Proterozoic lithospheric mantle fragment, based on the depleted nature and low pressure-temperature conditions of the mantle xenoliths. Our data support this model and further reveal distinct isotopic and trace element compositional differences between Tres Lagos and other Patagonian mantle xenoliths.

Previous studies suggest a Mesoproterozoic to early Paleozoic (Stern et al., 1999; Schilling et al., 2008) or even younger (Wang et al., 2008) formation of the SCLM beneath Pali Aike. However, our Re-Os data clearly show that the SCLM beneath Pali Aike was formed at least as long ago as early Paleoproterozoic times.

Crustal rocks of similar age close to the position of southernmost Patagonia in Gondwana occur only at Shackleton Range, a composite terrane located at the northwestern edge of the East

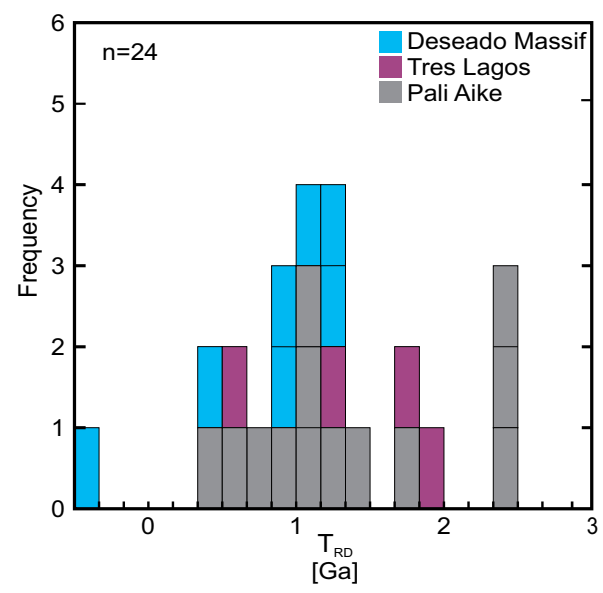

Figure 4. Histogram of calculated rhenium depletion ages $\left(T_{\mathrm{RD}}\right)$, comprising all $24 \mathrm{~Pa}$ tagonian spinel peridotites, using primitive mantle values from Meisel et al. (1996) $\left({ }^{187} \mathrm{Os} /{ }^{188} \mathrm{Os}=0.1296\right)$. 
Antarctic craton. U-Pb data from orthogneisses from the northern belt of Shackleton Range suggest granite emplacement at $2.3 \mathrm{Ga}$ (Brommer et al., 1999), indicating the existence of early Paleoproterozoic crust. U-Pb data from magmatic zircons in gneisses from the Shackelton Range's Southern Terrane document an additional slightly younger Paleoproterozoic (1.9 Ga) magmatic period in this region (Will et al., 2009). These ages match our determined $T_{\mathrm{RD}}$ ages from Pali Aike (2.5 Ga) and Tres Lagos (1.9 Ga) and hence suggest a common geological origin.

\section{CONCLUSIONS}

The Mesoproterozoic evolution of the SCLM beneath the Deseado Massif, southern Patagonia, is most likely connected to the formation of the Namaqua-Natal belt and hence was formed during the assembly of Rodinia. Osmium isotopic results show that, contrary to previous studies suggesting Mesoproterozoic to Paleozoic formation (Stern et al., 1999; Wang et al., 2008; Schilling et al., 2008), the SCLM beneath Pali Aike in southernmost South Patagonia was formed as early as the early Paleoproterozoic. We suggest that the SCLM underneath the southernmost part of Patagonia and southwest of the Deseado Massif is represented by late Archean to early Paleoproterozoic and mid-Paleoproterozoic fragments whose origin is connected to the geological evolution of Shackleton Range, Antarctica. These SCLM fragments accreted to the Deseado Massif probably during the formation of supercontinent Rodinia before drifting off together with the rest of South Patagonia during Gondwana breakup.

\section{ACKNOWLEDGMENTS}

This work was financed by Austrian Science Fund grant P 23557-N19 (Principal Investigator: Th. Ntaflos). We gratefully acknowledge W. Wegner (University of Vienna) for $\mathrm{Sr}$ and $\mathrm{Nd}$ isotope analyses; V. Erban (Czech Geological Survey) for Os isotope analyses; and J. Ďurišová (Czech Academy of Sciences) for inductively coupled plasma-mass spectrometry analyses of highly siderophile elements. We thank W.L. Griffin, J. Bédard, and two anonymous reviewers for their constructive comments to improve this manuscript. The editorial handling and suggestions by J.B. Murphy are greatly appreciated.

\section{REFERENCES CITED}

Alard, O., Griffin, W.L., Lorand, J.-P., Jackson, S.E., and O'Reilly, S.Y., 2000, Non-chondritic distribution of the highly siderophile elements in mantle sulphides: Nature, v. 407, p. 891-894, doi:10.1038/35038049.

Brandon, A.D., Creaser, R.A., Shirey, S.B., and Carlson, R.W., 1996, Osmium recycling in subduction zones: Science, v. 272, p. 861-863, doi: 10.1126/science.272.5263.861.

Brommer, A., Millar, I.I., and Zeh, A., 1999, Geochronology, structural geology and petrology of the northwestern Lagrange Nunataks, Shackleton Range, Antarctica: Terra Antarctica, v. 6, p. 269-278.

Bruhn, R.L., Stern, C.R., and De Wit, M.J., 1978, Field and geochemical data bearing on the development of a Mesozoic volcanotectonic rift zone and back-arc basin in southernmost South Amer- ica: Earth and Planetary Science Letters, v. 41, p. 32-46, doi:10.1016/0012-821X(78)90039-0.

Carlson, R.W., 2005, Application of the Pt-Re-Os isotopic systems to mantle geochemistry and geochronology: Lithos, v. 82, p. 249-272, doi: 10.1016/j.lithos.2004.08.003.

Dalziel, I.W.D., Mosher, S., and Gahagan, L.M., 2000, Laurentia-Kalahari collision and the assembly of Rodinia: The Journal of Geology, v. 108, p. 499513, doi: $10.1086 / 314418$.

D’Orazio, M., Agostini, S., Mazzarini, F., Innocenti, F., Manetti, P., Haller, M.J., and Lahsen, A., 2000, The Pali Aike Volcanic Field, Patagonia: Slab-window magmatism near the tip of South America: Tectonophysics, v. 321, p. 407-427, doi:10.1016/S0040-1951(00)00082-2.

Griffin, W.L., O’Reilly, S.Y., and Ryan, C.G., 1999a, The composition and origin of subcontintental lithospheric mantle, in Fei, Y., et al., eds., Mantle Petrology: Field Observations and High Pressure Experimentation: A Tribute to Francis F. (Joe) Boyd: Houston, Texas, The Geochemical Society, v. 6, p. 13-45.

Handler, R.M., Bennet, V.C., and Carlson, R.W., 2005, Nd, Sr and Os isotope systematics in young, fertile spinel peridotite xenoliths from northern Queensland, Australia: A unique view of depleted MORB mantle?: Geochimica et Cosmochimica Acta, v. 69, p. 5747-5763, doi: 10.1016/j.gca.2005.08.003.

Jacobs, J., Bauer, W., Spaeth, G., Thomas, R.J., and Weber, K., 1996, Lithology and structure of the Grenville-aged ( 1.1 Ga) basement of Heimefrontfjella (East Antarctica): Geologische Rundschau, v. 85 , p. $800-822$.

Kay, S.M., Ramos, V.A., Mpodozis, C., and Sruoga, P., 1989, Late Paleozoic to Jurassic silicic magmatism at the Gondwana margin: Analogy to the Middle Proterozoic in North America? Geology, v. 17, p. 324-328, doi:10.1130/0091 -7613(1989)017<0324:LPTJSM>2.3.CO;2.

König, M., and Jokat, W., 2006, The Mesozoic breakup of the Weddel Sea: Journal of Geophysical Research, v. 111, B12102, doi:10.1029 /2005JB004035.

Lorand, J.-P., Luguet, A., and Alard, O., 2013, Platinum-group element systematics and petrogenetic processing of the continental upper mantle: A review: Lithos, v. 164-167, p. 2-21, doi:10.1016/j.lithos.2012.08.017.

McCourt, S., Armstrong, R.A., Grantham, G.H., and Thomas, R.J., 2006, Geology and evolution of the Natal belt, South Africa: Journal of African Earth Sciences, v. 46, p. 71-92, doi:10.1016/j .jafrearsci.2006.01.013.

McDonough, W.F., and Sun, S., 1995, The composition of the Earth: Chemical Geology, v. 120, p. 223 253, doi:10.1016/0009-2541(94)00140-4.

Meisel, T., Walker, R.J., and Morgan, J.W., 1996, The osmium isotopic composition of the Earth's primitive upper mantle: Nature, v. 383, p. 517 520, doi:10.1038/383517a0.

Nowell, G.M., Kempton, P.D., Noble, S.R., Fitton, J.G., Saunders, A.D., Mahoney, J.J., and Taylor, R.N., 1998, High-precision Hf isotope measurements of MORB and OIB by thermal ionization mass spectrometry: Insights into the depleted mantle: Chemical Geology, v. 149, p. 211-233, doi:10.1016/S0009-2541(98)00036-9.

Ntaflos, Th., Bjerg, E.A., Labudia, C.H., and Kurat, G., 2007, Depleted lithosphere from the mantle wedge beneath Tres Lagos, southern Patagonia, Argentina: Lithos, v. 94, p. 46-65, doi: 10.1016/j.lithos.2006.06.011.

Pankhurst, R.J., Rapela, C.W., Loske, W.P., Márquez, M., and Fanning, C.M., 2003, Chronological study of the pre-Permian basement rocks of southern Patagonia: Journal of South American
Earth Sciences, v. 16, p. 27-44, doi:10.1016 /S0895-9811(03)00017-8.

Pankhurst, R.J., Rapela, C.W., Loske, W.P., Fanning, C.M., and Márquez, M., 2006, Gondwanide continental collision and the origin of Patagonia: Earth-Science Reviews, v. 76, p. 235-257, doi:10.1016/j.earscirev.2006.02.001.

Pearson, D.G., 1999, The age of continental roots: Lithos, v. 48, p. 171-194, doi:10.1016/S0024 -4937(99)00026-2.

Pearson, D.G., Shirey, S.B., Carlson, R.W., Boyd, F.R., Pokhilenko, N.P., and Shimizu, N., 1995, $\mathrm{Re}-\mathrm{Os}, \mathrm{Sm}-\mathrm{Nd}$, and $\mathrm{Rb}-\mathrm{Sr}$ isotope evidence for thick Archaean lithospheric mantle beneath the Siberian craton modified by multistage metasomatism: Geochimica et Cosmochimica Acta, v. 59 , p. $959-977$.

Ramos, V.A., 2008, Patagonia: A Paleozoic continent adrift?: Journal of South American Earth Sciences, v. 26, p. 235-251, doi:10.1016/j.jsames .2008.06.002.

Schilling, M.S., Carlson, R.W., Conceição, R.V., Dantas, C., Bertotto, G.W., and Koester, E., 2008, Re-Os isotope constraints on subcontinental lithospheric mantle evolution of southern South America: Earth and Planetary Science Letters, v. 268, p. 89-101, doi:10.1016/j .eps1.2008.01.005.

Stern, C.R., Frey, F.A., Futa, K., Zartman, R.E., Peng, Z., and Kyser, T.K., 1990, Trace-element and Sr, $\mathrm{Nd}, \mathrm{Pb}$, and $\mathrm{O}$ isotopic composition of Pliocene and Quaternary alkali basalts of the Patagonian Plateau lavas of southernmost South America: Contributions to Mineralogy and Petrology, v. 104, p. 294-308, doi:10.1007/BF00321486.

Stern, C.R., Kilian, R., Oker, B., Hauri, E.H., and Dyser, T.K., 1999, Evidence from mantle evolution for relatively thin $(<100 \mathrm{~km})$ continental lithosphere below the Phanerozoic crust of southernmost South America: Lithos, v. 48, p. 217-235, doi: 10.1016/S0024-4937(99)00030-4.

Thomas, R.J., Jacobs, J., and Eglington, B.M., 2000, Geochemistry and isotopic evolution of the Mesoproterozoic Cape Meredith Complex, West Falkland: Geological Magazine, v. 137, p. 537553, doi:10.1017/S0016756800004519.

Walker, R.J., and Morgan, J.W., 1989, Rheniumosmium isotope systematics of carbonaceous chondrites: Science, v. 243 , p. $519-522$, doi: 10.1126/science.243.4890.519.

Walker, R.J., Carlson, R.W., and Shirey, S.B., 1989, $\mathrm{Os}, \mathrm{Sr}, \mathrm{Nd}$, and $\mathrm{Pb}$ isotope systematics of southern African peridotite xenoliths: Implications for the chemical evolution of the subcontinental mantle: Geochimica et Cosmochimica Acta, v. 53, p. 1583-1595, doi:10.1016/0016-7037(89) 90240-8.

Wang, J., Hattori, K.H., Li, J., and Stern, C.R., 2008, Oxidation state of Paleozoic subcontinental lithospheric mantle below the Pali Aike volcanic field in southernmost Patagonia: Lithos, v. 105, p. 98-110, doi:10.1016/j.lithos.2008.02.009.

Will, T.M., Zeh, A., Gerdes, A., Frimmel, H.E., Millar, I.L., and Schmädicke, E., 2009, Palaeoproterozoic to Palaeozoic magmatic and metamorphic events in the Shackleton Range, East Antarctica: Constraints from zircon and monazite dating, and implications from the amalgamation of Gondwana: Precambrian Research, v. 172, p. 25-45, doi:10.1016/j.precamres.2009.03.008.

Zindler, A., and Hart, S., 1986, Chemical geodynamics: Annual Review of Earth and Planetary Sciences, v. 14, p. 493-571, doi:10.1146/annurev .ea.14.050186.002425.

Manuscript received 9 October 2014

Revised manuscript received 21 October 2014

Manuscript accepted 21 October 2014

Printed in USA 


\section{Geology}

\section{Mesoproterozoic and Paleoproterozoic subcontinental lithospheric mantle domains beneath southern Patagonia: Isotopic evidence for its connection to Africa and Antarctica}

Andrea Mundl, Theodoros Ntaflos, Lukas Ackerman, Michael Bizimis, Ernesto A. Bjerg and Christoph A. Hauzenberger

Geology 2015;43;39-42

doi: $10.1130 / G 36344.1$

\section{Email alerting services}

\section{Subscribe}

Permission request click www.gsapubs.org/cgi/alerts to receive free e-mail alerts when new articles cite this article

click www.gsapubs.org/subscriptions/ to subscribe to Geology

click http://www.geosociety.org/pubs/copyrt.htm\#gsa to contact GSA

Copyright not claimed on content prepared wholly by U.S. government employees within scope of their employment. Individual scientists are hereby granted permission, without fees or further requests to GSA, to use a single figure, a single table, and/or a brief paragraph of text in subsequent works and to make unlimited copies of items in GSA's journals for noncommercial use in classrooms to further education and science. This file may not be posted to any Web site, but authors may post the abstracts only of their articles on their own or their organization's Web site providing the posting includes a reference to the article's full citation. GSA provides this and other forums for the presentation of diverse opinions and positions by scientists worldwide, regardless of their race, citizenship, gender, religion, or political viewpoint. Opinions presented in this publication do not reflect official positions of the Society.

\section{Notes}

(C) 2014 Geological Society of America

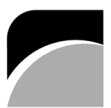

THE GEOLOGICAL SOCIETY OF AMERICA 